e ISSN-0976-7223 | Visit Us - www.researchjournal.co.in

DOI : 10.15740/HAS/JJAE/7.2/417-421

\title{
Impact of deep cultivation on run-off, soil and nutrient conservation in rainfed conditions
}

\section{S.M. TALEY, S.M. PONGDE AND S.C. VILHEKAR}

Received : 14.03.2014; Revised : 29.08.2014; Accepted : 11.09 .2014

See end of the Paper for authors' affiliation

Correspondence to :

\section{S.M. TALEY}

Dr. Panjabrao Deshmukh Krishi Vidyapeeth, AKOLA (M.S.) INDIA

Email : smtaley@ rediffmail.com
- ABSTRACT : A field experiment was conducted on cropping systems for in situ soil and moisture conservation during the Kharif season of 2012-13 at Agro-ecology and Environment Centre, Dr. P.D.K.V., Akola. The main objective was to estimate in situ soil and moisture conservation and to study the effect on crop growth and productivity. The experiment consisted of two crops viz., cotton (variety-AKA-7) and soybean (variety- JS-335) with eight treatments of cropping systems and cultivation practices. Data pertaining to the growth and yield of soybean (JS-335) and cotton (AKA-7) indicated the favorable effects of $30 \mathrm{~cm}$ deep cultivation in medium deep soil under sole and intercropping systems. Results on growth parameters revealed that the performance of soybean crop in terms of plant height, no. of branches, no. of pods, grain yield, straw yield and WUE under $30 \mathrm{~cm}$ deep cultivation was found better in both, sole $\left(\mathrm{T}_{5}\right)$ and intercropping systems $\left(\mathrm{T}_{7}\right)$ over shallow cultivation $\left(\mathrm{T}_{2}\right.$ and $\left.\mathrm{T}_{4}\right)$. The performance of the cotton crop in terms of plant height, no. of branches and picked bolls per plant, seed cotton, stalk yield and WUE under deep cultivation was found better in both, sole $\left(\mathrm{T}_{6}\right)$ and intercropping systems $\left(\mathrm{T}_{7}\right)$ over $\mathrm{T}_{3}$ and $\mathrm{T}_{4}$ under shallow cultivation. The maximum soil moisture content up to the depth of $60 \mathrm{~cm}$ was observed 11.08 to 17.86 per cent in $\mathrm{T}_{7}$ followed by $\mathrm{T}_{6}$ (10.96 to $17.17 \%$ ) and minimum in $\mathrm{T}_{5}\left(10.76\right.$ to $16.98 \%$ ). Over the treatment of $\mathrm{T}_{2}, \mathrm{~T}_{3}$ and $\mathrm{T}_{4}$, respectively. The maximum increase in soil moisture content was observed 10.12 to 15.94 per cent in $\mathrm{T}_{5}$ followed by $\mathrm{T}_{6}(8.25$ to $12.29 \%)$ and $\mathrm{T}_{7}(9.48$ to $10.79 \%)$ over the treatment of $\mathrm{T}_{2}, \mathrm{~T}_{3}$ and $\mathrm{T}_{4}$, respectively.

— KEY WORDS : Cropping system, Growth, Intercropping, Moisture, Water use efficiency

— HOW TO CITE THIS PAPER : Taley, S.M., Pongde, S.M. and Vilhekar, S.C. (2014). Impact of deep cultivation on run-off, soil and nutrient conservation in rainfed conditions. Internat. J. Agric. Engg., 7(2) : 417-421. 